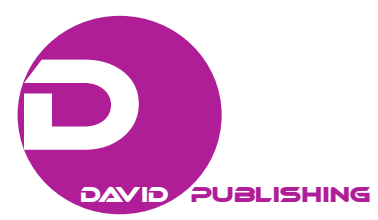

\title{
Innovation Management Processes and Routines for Business Success and Value Creation
}

\author{
Luís Vala \\ Independent Researcher, Lisbon, Portugal \\ Renato Pereira \\ OBSERVARE/UAL, Lisbon, Portugal; ISCTE-IUL, Lisbon, Portugal \\ Isabel Caetano \\ COTEC Portugal, Lisbon, Portugal; ISCTE-IUL, Lisbon, Portugal
}

\begin{abstract}
Innovation is managed through the development of processes and routines, considered as critical for business success and value creation. The identification of relevant routines as well as the understanding of which factors affect business innovation is the main objective of this research, based on a survey applied in Portuguese companies and their experience shared in best practices guides. Conclusions highlighted 10 key innovation routines, reinforcing the idea that innovation must be supported through a systematic and sustained management process. Results also indicate that SMEs face greater difficulties in benefiting from the potential of innovation practices and collaboration may present opportunities to overcome their limited resources. Therefore, regardless of size, business activity, science and technology intensity or other factors influencing firms dynamic capabilities, innovation should be considered as a management imperative as it can influence not only the present but also the future of business success.
\end{abstract}

Keywords: innovation management, innovation process, innovation routines, value creation, SMEs, Portugal

\section{Introduction}

Age of innovation, label proposed by Janszen (2000) characterizing the 20th century reality, includes three different stages contributing to world transformation. In the 50s and 60s, the age of efficiency emerged; in the 70s and 80s, the quality challenge and finally, after 1980, the age of flexibility. Nevertheless, the focus on innovation, as a key driver of competitiveness for societies, countries, and firms, has been present not only in a formalized way but also as a rhetoric resource in order to highlight its cultural and strategic dimension (Salter \& Alexy, 2014; Trott, 2012). Business success is normally associated with firm ability to create and distribute wealth but also to its differentiation, normally linked to innovation, in the market (Ketchen, Ireland, \& Snow, 2007). In this study, we analyzed how innovation processes are managed in Portuguese companies and what are the most important routines influencing innovation performance.

Luís Vala, M.Sc., independent researcher, Lisbon, Portugal.

Renato Pereira, Ph.D., researcher, OBSERVARE/UAL; Guest Professor, ISCTE-IUL, Lisbon, Portugal.

Isabel Caetano, M.Sc., manager, COTEC Portugal; Ph.D., student, ISCTE-IUL, Lisbon, Portugal.

Correspondence concerning this article should be addressed to Renato Pereira, Rua Santa Marta, 47, 1150-293 Lisbon, Portugal. 


\section{Innovation Management as a Systematic and Sustained Activity}

\section{Processes and Routines}

The complex, diverse, relational, and combinatorial characteristics of innovation determine that each innovation process is actually composed of several processes and routines aiming at value creation inside an organization. Those "learning routines" integrated and associated with organizational structures can facilitate innovation (Lam, 2005) as they accelerate knowledge diffusion, its absorption, and transfer. Also, recent national and international standards have been published endorsing the need of a systematic innovation management aligned with the innovation cycle of activities (CEN/TS 16555-1, 2013). These cycles should be repeated over time and recursively adjusted to create or renew core competences (Hamel \& Prahalad, 1990) necessary to overcome firm challenges such as the difficult balance between resource exploitation and resource exploration. In spite of recognizing that there are no guaranteed recipes for innovation success, some organizations have developed pragmatic ways of acting and putting innovation in practice, experiments, or patterns linked to an innovative-friendly culture (Tidd \& Bessant, 2009). Project management, intellectual property management, or idea management are just examples of some of those practices, normally supported in management processes and even certified through external audits. Other influences such as size, business activity, technological intensity, or region can also determine firm's adoption and development of management routines and their abilities to integrate its contribution towards efficiency and innovation performance.

Also, considering the need to be involved in an "open mode" (Chesbrough, 2003) for R\&D and innovation activities, firms tend to build knowledge sharing and collaboration routines. In the context of an open innovation model, firms rely on external sources of knowledge and ideas for identifying and leveraging innovation opportunities.

\section{Routines as Factors for Business Success}

Routines support innovation processes which are determinants to observe internal and external signs, to learn and to adapt to change requiring responses, proactive and competitive intelligence action.

Questions such as "How can opportunities for innovation be found?" or "How can knowledge be transferred and valued into innovative solutions?” are keys to innovation process management. Nevertheless, the essence of innovation lies in the capacity to identify opportunities and then proceed to the actions needed to explore its potential and create value. For that purpose, individuals and teams can develop skills that are considered essential for a more innovation-driven organizational culture. Dyer, Gregersen, and Christensen (2009) concluded, as a result of a six year study of habits of 500 entrepreneurs and a survey of more than 3,000 executives that there are five discovery skills: associating, questioning, observing, experimenting, and networking, which they called the "Innovator's DNA". Visionary, creative, and innovative entrepreneurs allocate resources, including time, energy, attention, and priority to these discovery activities and try to develop them throughout time.

\section{Market Surveillance and Monitoring}

Understanding consumers, users, competitors, value chain partners as well as their needs, expectations, and problems generates a powerful source of information, essential as an input, and a driver for innovation. A key aspect lies in recognizing market flaws and unmet needs and therefore identifying, developing, or anticipating an innovative solution. Also, consumers' ideas, users' experiences, and behavioral observation, as already developed through design thinking methodologies, can be crucial as starting points to explore new 
directions and scenarios for business innovation portfolio. Therefore, it is important to create mechanisms to understand and to absorb rich, challenging, and invaluable inputs from this direct contact with external sources. In a short and medium term, close, emphatic, and proactive linkages with clients are extremely relevant in order to maintain contact and learning routines (Freire, 2000). Within this context, routines such as visiting stores or sales points, organising regular stakeholders meetings or involving clients at advisory, collaborative, and consultative forums, are already applied (COTEC, 2010). The concept of "idea hunter" converges with this reasoning, arguing that people, especially firms' employees, must systematically search and discover ideas, contributing to their transformation into innovations. Named by scouts, full time or part time people will be exploring somewhat unpredictable places, and therefore obtaining valuable information which can include not only technological data concerning latest developments and progress but also emerging markets or trends, using complementary methods as ethnographic or “deep diving”.

Companies can integrate clients into the innovation generation process, due to their extensive knowledge about the needs of a particular group. Thus, in the case of non-industrial products, the challenge that companies face is to identify the so-called "lead users", who can be central in co-creating solutions, benefiting from their input in early stages of idea generation and new product concept formulation. Profiting from their willingness to experiment, to test, and to accept failure and risk, companies recognise the role users play in the innovation process, especially in what concerns potential product improvement during the test and prototyping phases (Tidd, Bessant, \& Pavitt, 2005). Information resulting from this involvement, as well as from other sources, including clients/customers satisfaction feedback concerning products, services, and market analysis, provides valuable contribution to business innovation process (COTEC, 2010).

Observing other players in the market is also deemed important for innovation. Tidd and Bessant (2009) regard "benchmarking, reverse engineering, and copying" as sources of innovation. When considering the knowledge base of the organization, Trott (2012) also includes competitors (as well as other companies, clients, and suppliers) as relevant to underpin firm innovative ability. With this in mind, the author mentions routines such as in-depth analysis of products introduced in the market by competitors, which can be carried out, for example, by collecting those products. In addition, newness characteristics of a product, service, or other innovative solutions (e.g. new business models or organizational methods) result from variations, combinations, or adaptations. So, surveying and analysing external markets can play a fundamental role in the development of innovations with potential to absorb and integrate.

Other information sources of innovation are used by firms as relevant contributors to different innovation enablers and processes. Media, in which the internet holds a prominent place, is seen as a powerful resource available for organizations (Tidd et al., 2005) for market and competitive intelligence, in order to identify trends and emerging needs, to detect warning signals, and to develop multiple linkages to community targets as scientists, knowledge providers, or other innovation stakeholders. In order to profit from this diverse and valuable potential, firms have already developed different IT systems and processes (e.g. intranets, web based communities) reinforcing collaboration and communication practices or organisational routines.

Other important resources for innovation ideas can easily be mentioned, for example, company reports, magazines, newspapers, business websites, international studies, press conferences, or the media (Freire, 2000).

\section{Valorisation of Scientific and Technological Knowledge}

The contribution of science for business innovation cannot be neglected and reflects one of the most 
relevant sources of knowledge which influences performance and value creation. Linkages with scientific infrastructures, laboratories, universities, and research oriented institutions have been reinforced, mainly targeting new product and services development and more frequently science-based and technological intensive sectors. But this relationship between firms and universities has been studied for decades as it presents many challenges, most of which are very difficult to overcome (Pavitt, 2005). For business managers, scientific advances and results are viewed as potential sources to innovation, if transferable and appropriable, thus depending on several conditions (e.g. time, cost, sector, technology field, etc.).

It was observed that companies, universities, or other research institutions develop collaboration agreements, launch joint projects, allocate resources to common R\&D laboratories and facilities, exchange and train people, and provide qualified human resources. Other routines can be identified as the production of national and international co-publications, patents, and other intellectual property rights (COTEC, 2010). Nevertheless, at business side, absorption capacity and expertise are needed to develop those skills and to maintain relevant linkages (Freire, 2000). Also, studies focusing technological trajectories and emergent science based research are very important to reinforce business forecasting (COTEC, 2010). Considering an open innovation context, firms may use external partners and benefit from a more diverse and collaborative model, creating value not only from within the organization but from the outside as well, in order to meet market needs (Chesbrough, 2003). In practical terms, this activity uses different tools and sources of information, including access to specialized publications, patent databases, trade fairs and conferences, standardization and regulatory committees (Freire, 2000; COTEC, 2010).

\section{Knowledge Management}

A broad range of activities can be included in this process, involving the generation, validation, codification, and dissemination of existing knowledge inside the firm but also the identification of needs for external knowledge. Assuming a systemic view of innovation, the entire organization must be involved in the process, not only specific departments (e.g., R\&D). It is necessary to improve employee engagement through different mechanisms and tools (Conway \& Steward, 2009; Tidd et al., 2005) and to develop a structured approach towards knowledge management. The idea that organizations must develop their knowledge base and skills is at the heart of the concept of learning organization, determining its ability to innovate (Trott, 2012). So, knowledge management strategies and processes combine different techniques and tools for employee engagement, training, and participation in the innovation process, through creative and frequently low cost initiatives gradually becoming routines (e.g., brown bag lunches, after action reviews or knowledge harvesting sessions).

The development of a community of practice ( $\mathrm{CoP})$ focusing knowledge development gathering more than 50 companies in Portugal is a good example of the recognition of its importance (Caetano, Filipe, \& Neves, 2014). Stimulating interaction between its members, CoP has been permitted to share information about knowledge management strategies, processes, and tools as well as best practices, including training sessions. Being present in Portugal since 1905, Siemens was a challenging partner that, together with other national and international players, recognized the importance of implementing knowledge management tools as Technoweb 2.0, an internal platform that enables employees to be connected to other colleagues, experts, and facilitates access to networks and knowledge clusters (COTEC, 2013).

In addition, participating in activities such as innovation related events-conferences, conventions, or seminars-is essential in order to promote knowledge sharing and diffusion (COTEC, 2010). Time and space to 
develop creativity and innovation opportunities, having experimentation and testing conditions, are important to encourage employee engagement and their commitment to an innovation journey, supported by top management (Tushman \& O’Reilly, 1997; Gibson \& Skarzynski, 2008).

In this context, organizational culture and environment influence the adoption and development of routines through which creativity and innovation could be stimulated and nurtured. Nevertheless, as it was observed in companies, routines such as innovation circles or workshops dedicated to discussing ideas, idea contests (through intranet and/or suggestions boxes normally used at factories or industrial sites), recognition, symbolic or incentives awards, have already been used (COTEC, 2010).

Also, intrapreneurship contributes to better exploit ambidexterity, encouraging specific projects, new business units, new ventures, new opportunities development, or virtual entrepreneurial initiatives (Pinchot, 1985; Wickham, 2006; Trott, 2012).

\section{Projects and Other Innovation Related Activities Management}

Innovation activities are normally organized as "projects" and their scope is broad and encompassing several business areas, practices, and processes. They require different organizational capabilities in order to achieve successful results and to be agile and efficient. From project selection to their implementation and control, several steps have to be taken, such as a continuous monitoring of the projects and a careful allocation of resources (COTEC, 2010). Some specific routines have been identified and highlighted as crucial to innovation management focusing on projects.

From idea to concept. Complementing the ideation activity, an idea evaluation phase is needed, referred by Epstein, Davila, and Shelton (2006) as "Structured Idea Management”, applying different criteria, often depending on firm strategy, risk analysis, portfolio balance, and resource availability. Apart from the decision process, firms have identified organizational routines including generation, capture, evaluation, selection, implementation, and diffusion (COTEC, 2010). Techniques such as brainstorming sessions, check lists, or SWOT analysis contribute to identifying the most qualified concepts that could be detailed in a feasibility study. Gibson and Skarzynski (2008) state that the following factors-presented in order of importance-must be taken into account when selecting ideas: (i) the "size of the idea", consisting in the existence of a real need associated with the idea, as well as a market potential for it; (ii) the "feasibility of the idea", which is checking if the idea is actually viable in a real context, and (iii) "profitability", measured by the return that may arise from exploring the idea.

Freire (2000) believes that it is important to analyze three different aspects: market relevance, potential revenue, and risk and return analysis, using accounting indicators such as the Internal Rate of Return (IRR), the Net Present Value (NPV), or the Investment Recovery Period (Payback Period).

Project implementation. A successful implementation is crucial since innovation is expected to result from it. Project management guidelines are useful and can be followed by organization, reducing risks and facilitating execution. As indicated by companies, project management should be aligned with the innovation strategy, including its scientific and technological goals if applicable, and focus on value creation (COTEC, 2010). From project selection to implementation and development, several activities were highlighted as success factors to achieve results, including project evaluation and risk management. Nevertheless, as admitted by Epstein et al. (2006), experimentation activities are essential for the development of an innovative concept. Building prototypes, such as 3-D Artifacts, process maps, or simulations, is essential for identifying 
weaknesses and aspects to be improved in different stages of innovation projects as well as to obtain clients and users contribution and to maximize project success (Tidd, Bessant, \& Pavitt, 2005; Freire, 2000).

Innovation launch. If ideas, or innovation opportunities, are already sufficiently mature, following several gates or processes aiming to reduce their risk and to reinforce potential success, innovation launch must be prepared either in the context of a project or in the framework of other business case or entrepreneurial initiatives (e.g., virtual or incubation business). Planning, coordination, and time to market are necessary in order to facilitate market introduction (Freire, 2000). Also, a combination of resources and competences from other disciplines inside the firm, such as marketing or logistics, is required to contribute to this milestone.

Continuous learning. In the context of project management, lessons learned are a good example of how organizations can absorb knowledge and disseminate it. But, apart from projects, interactions between departments or functional areas should be promoted and encouraged as relevant processes to create motivation and involvement in the innovation cycle. Learning from successes and failures permits to stimulate knowledge sharing and to integrate it in future activities, improving performance (Tidd \& Bessant, 2009). Also, even if ideas or projects are not implemented, interrupted, or failed, information should be retained as it can still be valuable in different circumstances. For that, a portfolio of ideas should be created to record all generated ideas as well as decision criteria applied, facilitating assessment in the future, if needed. Other innovation routines sustain a learning perspective, as programme or project review meetings, case studies, innovation audits, or assessment exercises, frequently aligned with knowledge management processes. It is relevant to define methodologies, evaluation criteria, critical variables, and indicators depending on the type of innovation or the object of study (Freire, 2000).

\section{Empirical Study}

\section{Hypotheses}

Considering that specific skills are needed to nurture innovative activities in a systemic and systematic way, research was developed to understand which routines could be critical in order to build an innovative organization and its ability to capture innovation value.

Hypothesis 1: Is the distribution of the importance given to the more relevant routines of the innovation process the same for companies with innovative success and companies without innovative success?

Hypothesis 2: Is the impact of adopting innovations the same for Small and Medium Companies as it is for large companies?

\section{Data}

Following a test phase, in four different companies, a questionnaire was prepared and sent out to the AICEP company database, aggregating already exporting companies and/or those interested in exporting.

After this approach, through which companies were to answer if they consider themselves as innovative, the questionnaire was emailed to approximately 3,000 companies from which $78 \%$ are SMEs and $22 \%$ are large companies.

The success rate of responses was limited, less than $5 \%$, but still enabling an interesting analysis of 128 valid responses, 16 from large companies and 112 from SMEs.

\section{Variables}

Two groups of variables were considered: 
I-Company Profile. In this group, the following variables were defined:

X1-Type of company: This qualitative ordinal variable aims at differentiating companies by size. It applied the European Union definition of SME considering in that category those companies "which employ less than 250 people and which have an annual turnover not exceeding EUR 50 million, and/or a total annual balance sheet not exceeding EUR 43 million” (Commission Recommendation, 2003).

X2-Impact on the company of adopting innovation: In order to distinguish successful companies in the innovation process, a quantitative ordinal variable was applied. Evaluation of innovation impact on economic and financial results, in the previous three years, should be indicated using a scale from 1 (Not important) to 6 (Extremely important). A new qualitative nominal variable (Y3) results from the obtained answers and permits to identify two separate groups of companies: companies with innovative success and companies without innovative success.

II-Innovation Routines. This second group of variables is based on the theoretical framework already presented. As indicated in the following table (Table 1), variables consider the importance of carrying out specific routines (Y), in a total of 22, for the success of the innovation process.

Using a scale of 1 (Not important) to 5 (Extremely important), companies can also not respond if they do not apply that routine or if they do not consider it as relevant in their innovation context.

Table 1

Importance of Routines for Innovation Success

\begin{tabular}{|c|c|}
\hline Variables & Investigated routines \\
\hline Y1 & $\begin{array}{l}\text { Information from foreign markets is collected in order to follow their evolution and to identify opportunities to } \\
\text { import valuable ideas }\end{array}$ \\
\hline Y2 & $\begin{array}{l}\text { Company keeps up to date with technological improvements that might be relevant for business (e.g., machinery } \\
\text { or software) }\end{array}$ \\
\hline Y3 & Company follows closely the activity of its competitors \\
\hline Y4 & Company has field staff who interact directly with the client/consumer in order to perceive its needs \\
\hline Y5 & Company takes part in innovation events (for example, fairs, meetings, or conferences) \\
\hline Y6 & $\begin{array}{l}\text { Company provides training activities to employees in the field of innovation targeting the continuous } \\
\text { improvement of the organisation }\end{array}$ \\
\hline Y7 & $\begin{array}{l}\text { Company searches the Internet (social networks, review websites, among others) for opinion collection and } \\
\text { emerging trends observation }\end{array}$ \\
\hline Y8 & Company prepares market evolution plans to anticipate change \\
\hline Y9 & Company carries out internal audits in order to find solutions for potential problems \\
\hline Y10 & $\begin{array}{l}\text { Company subscribes periodical publications related to innovation, or which are relevant for researching its } \\
\text { business field }\end{array}$ \\
\hline Y11 & Consumer surveys are carried out regularly to understand if improvements can be made at product level \\
\hline Y12 & Consumer surveys are made regularly to understand if there are needs not currently being met by the market \\
\hline Y13 & Company integrates consumers as part of the innovation process \\
\hline Y14 & Company carries out scientific and technological research activities \\
\hline Y15 & Company carries out market studies \\
\hline Y16 & Company conducts thorough project management activities to make sure they are developed as intended \\
\hline Y17 & Feasibility studies are conducted on selected innovation projects \\
\hline Y18 & Company defines criteria as well as strategic and budget limits to support project selection and adoption \\
\hline Y19 & Innovation development is carried out in multidisciplinary teams to obtain a greater diversity of perspectives \\
\hline Y20 & Knowledge generated by each project is disseminated throughout the organisation \\
\hline Y21 & Company makes reports containing the results of the adopted innovations \\
\hline Y22 & Company holds a portfolio where all the ideas are recorded, even those that are not adopted \\
\hline
\end{tabular}




\section{Results}

Based on the variables associated with routines ( $Y$ ) with higher mean values (exceeding 4.0), it was possible to identify key routines for successful innovation in Portuguese companies.

In order to understand if the distribution of importance given to the most relevant routines of the innovation process is the same for companies with innovation success and for companies without innovation success, we used a Mann-Whitney nonparametric test to investigate Hypothesis 1, assessing the equality of distributions (medians) of a quantitative or ordinal variable implemented in two independent groups.

H0: $\mathrm{F}(\mathrm{X} 1)=\mathrm{F}(\mathrm{X} 2)$ vs. H1: $\mathrm{F}(\mathrm{X} 1)$ \# $\mathrm{F}(\mathrm{X} 2)$ for a bilateral test

H0: $F(X 1)<=F(X 2)$ vs. H1: $F(X 1)>F(X 2)$ for an unilateral test on the right

H0: $F(X 1)>=F(X 2)$ vs. H1: $F(X 1)<F(X 2)$ for an unilateral test on the left

In Table 2, in addition to the mean, we present the test values for each variable, as well as the corresponding decision for each of the tests carried out. Thus, in the context of hypothesis 1, 10 different key tests were performed—one key test per innovation routine.

Table 2

Hypotheses and Tests Results Regarding H1

\begin{tabular}{|c|c|c|c|c|c|}
\hline Var. & $\begin{array}{l}\text { Routines to perform hypothesis test } \\
\text { (level of significance }=0.05 \text { ) }\end{array}$ & Mean value & Test value & Sig. & Decision \\
\hline Y1 & $\begin{array}{l}\text { Information from foreign markets is collected, in order to follow their } \\
\text { evolution and to identify opportunities to import valuable ideas }\end{array}$ & 4.65 & 1009.000 & 0.002 & Reject \\
\hline Y2 & $\begin{array}{l}\text { Company keeps up to date with technological improvements that } \\
\text { might be relevant for business (e.g., machinery or software) }\end{array}$ & 4.47 & 1023.000 & 0.004 & Reject \\
\hline Y4 & $\begin{array}{l}\text { Company has field staff who interact directly with the } \\
\text { client/consumer in order to perceive its needs }\end{array}$ & 4.46 & 904.000 & 0.262 & Not reject \\
\hline Y3 & Company follows closely the activity of its competitors & 4.43 & 1106.000 & 0.030 & Reject \\
\hline Y5 & $\begin{array}{l}\text { Company takes part in innovation events (for example, fairs, } \\
\text { meetings, or conferences) }\end{array}$ & 4.34 & 947.000 & 0.017 & Reject \\
\hline Y16 & $\begin{array}{l}\text { Company conducts thorough project management activities to make } \\
\text { sure they are developed as intended }\end{array}$ & 4.21 & 816.500 & 0.029 & Reject \\
\hline Y6 & $\begin{array}{l}\text { Company provides training activities to employees in the field of } \\
\text { innovation targeting the continuous improvement of the organisation }\end{array}$ & 4.08 & 952.000 & 0.021 & Reject \\
\hline Y18 & $\begin{array}{l}\text { Company defines criteria as well as strategic and budget limits to } \\
\text { support project selection and adoption }\end{array}$ & 4.02 & 636.000 & 0.004 & Reject \\
\hline Y7 & $\begin{array}{l}\text { Company searches the Internet (social networks, review websites, } \\
\text { among others) for opinion collection and emerging trends observation }\end{array}$ & 4.01 & 885.500 & 0.027 & Reject \\
\hline Y17 & Feasibility studies are conducted on selected innovation projects & 4.00 & 806.500 & 0.055 & Not reject \\
\hline
\end{tabular}

In what concerns the second hypothesis (H2), it applied another Mann-Whitney nonparametric test and the following results were obtained:

Table 3

Hypotheses and Tests Results Regarding $\mathrm{H} 2$

\begin{tabular}{llll}
\hline Hypothesis test (level of significance $=0.05)$ & Test value & Sig. & Decision \\
\hline $\begin{array}{l}\text { H2: The distribution of the impact that results from adopting the innovation is } \\
\text { the same for SME as it is for large companies }\end{array}$ & \multirow{2}{*}{0.024} & \multirow{2}{*}{ Reject } \\
\hline
\end{tabular}

\section{Discussion and Conclusions}

The idea that innovation can be systematically managed reinforces the importance of identifying the key 
elements, determinants, processes, or routines that can be implemented, stimulated, and nurtured. Also, it is evident from data obtained through the questionnaires responses that most successful innovative companies envisage innovation not as an isolated event, whose occurrence results from a mere coincidence, but as a process that can be anchored in dynamic capabilities, most of which developed and carried out through formal and informal procedures, facilitating knowledge appropriation, transfer, and its transformation into new products, services, and other innovation results in a sustained way.

One of the main challenges of this research derives from its focus on the elements that can be identified and replicated in organisations in order to achieve an innovative path and its impact in competitiveness. Generally characterised as best practices, and previously presented on the theoretical framework applied, several routines are linked to innovation development. In spite of its complexity, ambidexterity, and dynamic, innovation process reflects common routines that can be observed among companies that achieved positive results with innovation, and which could be replicated in any company.

Concerning hypothesis 1 , it was demonstrated that companies revealing innovation success develop routines that contribute to their economic and financial results. This conclusion supports the perspective that innovation can be a process duly formalised and managed, including procedural events. Therefore, innovation requires a combination of capabilities and competences that, together with the appropriate routines, converges towards value creation through innovation activities and results.

Key routines of the innovation process, resulting from this research and which provide an answer to the main research question, highlight the adoption of an open, interactive, and systematic innovation management model and can be stylised in the following 10 routines in three specific areas:

1. Knowledge diffusion and innovation opportunities exploration:

- Collect information from foreign markets, in order to follow their evolution and to identify opportunities to import valuable ideas;

- Keep up to date with technological improvements that might be relevant for business, such as machinery or software;

- Have field staff who interact directly with the consumers in order to perceive their needs;

- Follow closely the activity of its competitors;

- Take part in innovation events, such as fairs, meetings, or conferences.

2. Innovation activity and project definition, selection and implementation:

- Define criteria as well as strategic and budget limits to substantiate the selection and adoption of projects;

- Supervise the innovation projects to make sure they are developed as intended;

- Conduct feasibility studies regarding the selected innovation projects.

3. Continuous learning:

- Provide training activities in the field of innovation to employees, with a view to the continuous improvement of the organization;

- Search the Internet (social networks, review websites, among others) for opinions and emerging trends.

Conclusions converge with literature review findings and some authors have already proposed the adoption of similar routines. To collect information from external markets and to follow competitors (Tidd \& Bessant, 2009), to be aware of technological innovations relevant for business and to participate in innovation events (Freire, 2000), to involve people interacting with consumers/clients to capture their needs (Conway \& Steward, 2009) are examples already referred as vital for business innovation success. Therefore, a possible 
barrier for that success results from the reduced investment in innovation activities, visibly aggravated during the financial crisis in some countries, and in its enablers and processes such as those referred as key routines.

Regarding the discussion of the second hypothesis, it was observed that large companies reveal better results than SMEs. From a resources perspective, it could be explained through the discrepancy of resource allocation to innovation and its influence on results. SMEs have limited financial capacity, even considering that public policies and funding have been supporting firms in their R\&D and innovation activities and projects, generating a barrier to innovation practices adoption and development when compared to large companies. Realizing that collaboration can be an alternative to overcome those obstacles has led many SMEs to opt for an open innovation strategy, exploring new opportunities in complementary and partnership solutions (Ketchen et al., 2007). Chesbrough (2003) highlighted that value creation can involve different actors, thus leveraging external resources and accessing diverse sources of knowledge, regardless of firm boundaries. This approach sustains a new way of developing innovation, assuming that firms are not isolated and must reinforce their linkages to other innovation actors from local, national, or international ecosystems. In that scenario, more efficient solutions can be designed and obtained through different types of cooperation with various participants, by acquiring, creating, complementing, and sharing information, knowledge, or resources (Carlson, 2003).

The issue of limited resources that small companies face may not be the only explanation for the different results across the groups. Focus on corporate agility, strategy, and its alignment with innovation requires dynamic capabilities that in less mature organizations simply do not exist or are very fragile, blocking knowledge transformation, adaptation to change, and innovation development (Teece, Gary, \& Shuen, 1997). Eisenhardt and Martin (2000) characterize those capabilities as “firm’s processes”, mainly organizational and strategic routines, through which organizations achieve resource configurations essential to cope with change.

As Simões (1997) has concluded two decades ago, "innovation is not, in general, an essential element in the strategy of Portuguese SMEs", situation has been evolving mainly influenced by a broader awareness of the importance of innovation as a driver of competitiveness. Results from CIS (2012) also confirm that Portuguese companies pay more attention to innovation, which is of particular importance since a proactive attitude concerning innovation enables adoption of systematic processes and routines and continuously improves the pursuit of excellence.

During the period 2010-2012, 33\% of the Portuguese companies have developed organizational innovation, including new organizational methods and new business management practices (CIS, 2012). Therefore, organizations realize that innovation should be linked to global strategy, supported through functional and specialized processes and considered as a driver for value creation.

Given the role played by SMEs in the Portuguese business landscape, a greater strategic investment in innovation would lead to an increase in their competitiveness, thereby leading to economic growth in a country that is so desperately in need of such stimulus. Apart from sustained public investment, private sector needs to maintain stable and continuous stimulus for innovation, using different learning mechanisms and tools to develop projects and initiatives supporting not only daily but also competitive challenges in a longer term scenario. Innovation routines can generate a positive impact in business performance, as demonstrated previously in the Portuguese context, accelerating building and adaptation of firm dynamic capabilities. 


\section{References}

Caetano, I., Filipe, I., \& Neves, A. (2014). Ferramentas de Gestão do Conhecimento: Principais Critérios de Selecção. Lisboa: COTEC Portugal.

Carlson, S. (2003). Knowledge managing and knowledge management system in inter organizational networks. Knowledge and Process Management, 10, 4-28.

CEN/TS 16555-1. (2013). Innovation management-Part 1: Innovation management system. Brussels: CEN.

Chesbrough, H. (2003). The era of open innovation. MIT Sloan Management Review, 44(1), 35-42.

CIS (Community Innovation Survey).

(2012). http://www.dgeec.mec.pt/np4/207/\%7B\$clientServletPath\%7D/?newsId=113\&fileName=Resultados_CIS_2012.pdf

Conway, S., \& Steward, F. (2009). Managing and shaping in innovation. Oxford: OUP.

COTEC. (2010). Guia de Boas Práticas de Gestão de Inovação. Lisboa: MBV Design. http://www.cotecportugal.pt/images/stories/iniciativas/DSIE/FaseII/guia_boas_praticas.pdf

COTEC. (2013). Cartas de Gestão de Conhecimento. Lisboa: Go Design. http://barometro.cotecportugal.pt/docs/community/Carta_Partilhar_Web.pdf

Dyer, J. H., Gregersen, H. B., \& Christensen, C. M. (2009). The innovator's DNA. Harvard Business Review, 87(3), 101-124.

Eisenhardt, K. M., \& Martin, J. A. (2000). Dynamic capabilities: What are they? Strategic Management Journal, 21(10/11), 1105-1121.

European Commission. (2003). Commission recommendation 2003/EC/361. Official Journal of the European Union, L 124/36.

Epstein, M. J., Davila, T., \& Shelton, R. (2006). Making innovation work: How to manage it, measure it and profit from it. London: Pearson Education.

Freire, A. (2000). Inovação, Novos produtos, Serviços e Negócios para Portugal. Lisboa: Verbo.

Gibson, R., \& Skarzynski, P. (2008). Innovation to the core: A blueprint for transforming the way your company innovates. Boston: Harvard Business School Press.

Hamel, G., \& Prahalad, C. K. (1990). The core competence of the corporation. Harvard Business Review, 68(3), 125-138.

Janszen, F. (2000). The age of innovation: Making business creativity a competence, not a coincidence. London: Financial Times/ Prentice Hall.

Ketchen, D. J., Ireland, R. D., \& Snow, C. C. (2007). Strategic entrepreneurship, collaborative innovation, and wealth creation. Strategic Entrepreneurship Journal, 1(3), 271-385.

Lam, A. (2006). Organizational innovation. In J. Fagerberg and D. C. Mowery (Eds.), The Oxford Handbook of Innovation (pp. 115-147). New York, NY: Oxford University Press.

Pavitt, K. (2005). Innovation processes. In J. Fagerberg and D. C. Mowery (Eds.), The Oxford handbook of innovation (pp. 86-114). New York, NY: Oxford University Press.

Pinchot, G. (1985). Intrapreneuring: Why you don't have to leave a corporation to become an entrepreneur. New York: Harper and Row.

Salter, A., \& Alexy, O. (2014). The nature of innovation. In M. Dodgson, D. M. Gann, and N. Phillips (Eds.), The Oxford handbook of innovation management. New York, NY: Oxford University Press.

Simões, V. (1997). Inovação e Gestão em PME. Lisboa: Ministério da Economia-Gabinete de Estudos e Prospectiva Económica.

Teece, D. J., Gary, P., \& Shuen, A. (1997). Dynamic capabilities and strategic management. Strategic Management Journal, 18(7), 509-533.

Tidd, J., Bessant, J., \& Pavitt, K. (2005). Managing innovation: Integrating technological, market and organizational change. New York: John Wiley \& Sons.

Tidd, J., \& Bessant, J. (2009). Managing innovation: Integrating technological, market and organizational change. New York: John Wiley \& Sons.

Trott, P. (2012). Innovation management and new product development. London: FT Prentice Hall.

Tushman, M. L., \& O’Reilly, C. A. (1997). Winning through innovation: A practical guide to leading organizational change and renewal. Boston: Harvard Business School Press.

Wickham, P. A. (2006). Strategic entrepreneurship. London: Financial Times/Prentice Hall. 